\title{
Pengaruh Job Insecurity dan Job Stres Terhadap Kepuasan Kerja Karyawan Dalam Issue Covid 19 Pada PT. X
}

\author{
$1 \mathrm{M}$ fauzi aldiassajjad, 2Sri Suwarsi
}

\author{
Prodi Manajemen Bisnis, Fakultas Ekonomi dan Bisnis, Universitas Islam \\ Bandung, Indonesia.
}

1 fauzialldiassajjad@gmail.com,2 dr.srisuwarsi@gmail.com

\begin{abstract}
This study aims to find out 1) Job insecurity on the Covid 19 issue at the PT Mitra Sarana Purnama company 2) Job stress on the Covid 19 issue at the PT Mitra Sarana Purnama company 3) Job satisfaction on the Covid 19 issue at the PT Mitra Sarana Purnama company 4) The effect of job insecurity on employee job satisfaction on the Covid 19 issue at PT Mitra Sarana Purnama 5) the effect of job stress on employee job satisfaction on the Covid 19 issue at PT Mitra Sarana Purnama 6) the effect of job insecurity and job stress on employee job satisfaction in the Covid 19 issue at PT Mitra Sarana Purnama. The research method used is descriptive research and verification research and operates the calculations using the SPSS 26 program. The variables in this study are Job Insecurity, Job stress and employee job satisfaction. Respondents in this study were permanent employees at PT Mitra Sarana Purnama totaling 65 people, with saturated sampling technique. The results of this study conclude that: 1) Job Insecurity variable in the covid-19 issue at PT Mitra Sarana Purnama Bandung is in the sufficient category. 2) Job Stress variable in the Covid-19 issue at PT Mitra Sarana Purnama Bandung is in the sufficient category. 3) Employee job satisfaction in the Covid-19 issue at PT Mitra Sarana Purnama Bandung is in the very high category 4) There is a low influence of $38.02 \%$ between Job Insecurity on employee job satisfaction in the issue covid 19.5) there is a low effect of $31.32 \%$ between job stress on employee job satisfaction in the covid 19 issue 6) Job insecurity and job stress have a significant effect on employee job satisfaction in the covid 19 issue. It can be concluded that there is an effect of job insecurity and Job Stress on employee job satisfaction in the Covid 19 Issue at PT Mitra Sarana Purnama.
\end{abstract}

Keywords: Job Insecurity, Job Stress, employee job satisfaction

Abstrak. Dalam penelitian ini bertujuan untuk mengetahui 1) Job insecurity pada issue Covid 19 di perusahaan PT Mitra Sarana Purnama 2) Job Stress pada issue Covid 19 di perusahaan PT Mitra Sarana Purnama 3) Kepuasan kerja pada issue Covid 19 di perusahaan PT Mitra Sarana Purnama 4) Pengaruh Job insecurity terhadap Kepuasan kerja karyawan pada issue Covid 19 di PT Mitra Sarana Purnama 5) pengaruh job stress terhadap kepuasan kerja karyawan pada issue Covid 19 di PT Mitra Sarana Purnama 6) pengaruh Job insecurity dan Job Stress terhadap kepuasan kerja karyawan pada issue Covid 19 di PT Mitra Sarana Purnama.. Metode penelitian yang digunakan adalah penelitian deskriptif dan penelitian verifikatif dan mengoprasikan perhitungannya menggunakan program SPSS 26. yang mana variabel dalam penelitian ini Job Insecurity,Job stress dan kepuasan kerja karyawan. Responden yang ada pada penelitian ini adalah Karyawan tetap pada PT Mitra Sarana Purnama yang berjumlah 65 orang, dengan Teknik pengambilan sampel jenuh. Hasil penelitian ini menyimpulkan bahwa:1) Variabel Job Insecurity dalam issue covid-19 yang berada di perusahaan PT Mitra Sarana Purnama Bandung berada di dalam kategori cukup.2) Variabel Job Stress dalam issue Covid-19 yang berada di perusahaan PT Mitra Sarana Purnama Bandung berada di dalam kategori cukup.3) Kepuasan kerja karyawan dalam issue Covid-19 yang berada di perusahaan PT Mitra Sarana Purnama Bandung berada di dalam kategori sangat tinggi 4)terdapat pengaruh rendah sebesar 38,02\% antara Job Insecurity terhadap kepuasan kerja karyawan dalam issue covid 19. 5)terdapat pengaruh rendah sebesar 31,32\% antar Job Stress terhadap Kepuasan Kerja karyawan dalam issue covid 19 6) Job Insecurity dan Job Stress berpengaruh secara signifikan terhadap kepuasan kerja karyawan dalam issue covid 19. Dapat disimpulkan bahwa terdapat pengaruh Job Insecurity dan Job Stress terhadap kepuasan kerja karyawan dalam Issue Covid 19 Di PT Mitra Sarana Purnama)

Kata Kunci: Job Insecurity, Job Stress, kepuasan kerja karyawan 


\section{A. Pendahuluan}

Akhir tahun 2019 masyarakat seluruh dunia di hebohkan dengan munculnya suatu wabah baru yang berasal dari virus, yang mana virus ini sangat berbahaya bagi manusia yaitu Coronavirus disease 2019 atau SARS-CoV-2 atau yang terkenal dengan sebutan Covid 19. Menurut (WHO, 2021) sudah lebih dari 100 negara di dunia terjangkit wabah pandemic Covid 19 Dan menurut hasil penelitian yang dilakukan oleh (WHO, 2021), Per bulan Mei angka masyarakat yang terpapar virus Covid 19 di Benua Asia khususnya Asia tenggara memiliki angka terpapar virus Covid 19 yang sangat tinggi. Di Indonesia sendiri, kasus Covid 19 sangat mengkhawatirkan. Bahkan dalam lima bulan terakhir kasus Covid 19 di Indonesia mengalami peningkatan kasus secara drastis dengan grafik yang selalu menanjak. (KEMENKES, 2021).

Dari adanya wabah pandemic Covid 19 ini, hampir seluruh sector kehidupan masyarakat Indonesia terganggu dan terdampak. Di tambah lagi kini pemerintah membuat kebijakan guna menekan angka kasus Covid 19 dengan melakukan program Pembatasan Sosial Bersekala besar (PSBB) yang mana menurut (pemerintah, 2020) dengan dibuatnya peraturan seperti ini bertujuan untuk mengurangi angka penyebaran Covid 19 di Indonesia.

Semenjak dilakukannya Pembatasan social berskala besar, banyak para pelaku usaha atau bisnis harus memutar otak, yang mana para pelaku bisnis harus mempersiapkan strategi, bukan hanya mempertahanakan bisnis nya saja tetapi mempertahankan kepuasan kerja karyawannya. Karena dalam masa pandemic saat ini kepuasan kerja merupakan aspek penting yang harus di jaga. karena menurut (Riana, 2015) kepuasan kerja itu suatu perasaan seornag karyawan mengenai pekerjaannya, sehingga dapat merasakan hal positif atau negatif yang dapat mempengaruhi kognisi karyawan.

PT Mitra Sarana purnama kota Bandung merupakan perusahaan yang berdiri ada tahun 2002 yang saling bekerja sama dengan perusahaan Lassalefood Indonesia. Pt Mitra Sarana purnama ini bergerak dalam bidang pemasaran dan manufaktur serta contract manufacturing makanan dan minuman, baik merek dagang sendiri ataupun merek dagang yang berada dibawah lisensi, selain itu PT Mitra sarana Purnama merupakan perusahaan distributor terkenal di berbagai macam kota di Indonesia. Terdapat lima lini bisnsis yang dimiliki oleh PT Mitra Sarana Purnama yaitu saus (Sauce Line), sirup (syrup line), pengalengan (canning line), konsentrate / sari buah (concentrate line) dan Mayonnaise serta Dressing line.

Dalam hal ini penulis melakukan wawancara serta melakukan pra survey di PT Mitra Sarana Purnama, dan dari hasil wawancara dan pra survey tersebut bahwa kepuasan kerja di perusahaan tersebut masih kurang di perhatikan, dan yang menjadi permasalahan utama yang mempengaruhi kepuasan kerja di masa pandemic ini yaitu ketidakamanan kerja (Job Insecurity) yang sangat tinggi yang mana menurut (A.A Gede Agung Januartha, 2019) Job insecurity itu suatu kegeliasahan yang ada pada diri karyawan yang langsung dapat mempengaruhi kepuasan kerja dan juga selain job Insecurity tingkat stress kerja (Job Stress) di PT Mitra sarana yang masih tinggi, dan menurut (I Gede Putro Wibowo, 2015) semakin tinggi tingkat Job Stress yang dirasakan karyawan semakin rendah tingkat kepuasan kerja karyawan dan sebaliknnya semakin rendah tingkat Job Stress yang di rasakan karyawan maka semakin tinggi tingkat kepuasan kerja karyawan.Hal ini lah yang menjadi suatu permasalahan yang terjadi di PT Mitra Sarana Purnama dalam masa Pandemic Covid 19.

Berdasarkan latar belakang penelitian diatas maka peneliti bermaksud meneliti lebih lanjut dengan judul: Pengaruh Job Insecurity dan Job Stress terhadap Kepuasan Kerja karyawan dalam issue Covid 19 pada PT Mitra Sarana Purnama.

Tujuan penelitian ini adalah:

1. Untuk mengetahui dan menganalisis Job insecurity pada issue Covid 19 di perusahaan PT Mitra Sarana Purnama.

2. Untuk mengetahui dan menganalisis Job Stress pada issue Covid 19 di perusahaan PT Mitra Sarana Purnama

3. Untuk mengetahui dan menganalisis kepuasan kerja pada issue Covid 19 di perusahaan PT Mitra Sarana Purnama.

4. Untuk mengetahui dan menganalisis seberapa besar pengaruh Job insecurity terhadap kepuasan kerja karyawan pada issue Covid 19 di PT Mitra Sarana Purnama. 
5. Untuk mengetahui dan menganalisis seberapa besar pengaruh Job Stress terhadap kepuasan kerja karyawan pada issue Covid 19 di PT Mitra Sarana Purnama.

6. Untuk mengetahui dan menganalisis seberapa besar pengaruh Job insecurity dan Job Stress terhadap kepuasan kerja karyawan pada issue Covid 19 di PT Mitra Sarana Purnama.

\section{B. Metodologi Penelitian}

Metode penelitian yang digunakan di dalam penelitian ini yaitu penelitian deskriptif dan verifikatif dengan pendekatan kuantitatif. Dalam hal ini Penelitian deskriptif digunakan untuk mengetahui serta menganalisis bagaimana Job Insecurity, Job Stress, dan Kepuasan kerja secara faktual di PT Mitra Sarana Purnama. Kemudian Penelitian verifikatif dipilih untuk mengetahui serta menjawab rumusan atas seberapa besar pengaruh Job Insecurtiy dan Job stress terhadap kepuasan kerja karyawan PT Mitra Sarana Purnama.

Metode penelitian yang digunakan dalam penelitian ini adalah dengan penelitian kuantitatif. Metode kuantitatif yaitu suatu metode yang dipakai atau digunakan untuk meneliti populasi atau sampel dalam suatu penelitian, pengumpulan data menggunakan instrumen penelitian dan dianalisa secara statistik untuk mengetahui uji hipotesis yang telah ditetapkan. Yang mana dalam hal ini populasi dan sampel penelitian berjumlah 65 orang, dengan ppengambilan sampel menggunakan metode Teknik sampling jenuh yang mana ini merupakan Teknik penentuan sampel bila seluruh anggota populasi digunakan sebagai sampel.

\section{Hasil Penelitian dan Pembahasan}

Tabel 1. Rekapitulasi Skor Variabel Job Insecurity

\begin{tabular}{|c|c|c|c|}
\hline Indikator & $\begin{array}{l}\text { Rata-rata } \\
\text { Skor }\end{array}$ & $\%$ & Keterangan \\
\hline $\begin{array}{l}\text { Adanya Perubahan } \\
\text { Negatif yang } \\
\text { Berdampak pada } \\
\text { Keseluruhan Pekerja }\end{array}$ & 221,75 & 60,29 & tinggi \\
\hline $\begin{array}{l}\text { Arti dan Makna Penting } \\
\text { Sebuah Pekerjaan }\end{array}$ & 197 & 50,77 & Cukup \\
\hline $\begin{array}{l}\text { Ketidakberdayaan } \\
\text { (Powerlesness) }\end{array}$ & 246 & 69,61 & tinggi \\
\hline Rata-rata & 221,58 & 60,22 & tinggi \\
\hline
\end{tabular}

Berdasarkan Tabel 1 dapat dilihat bahwa nilai dari rata-rata jawaban responden mengenai variabel Job Insecurity berjumlah 221,58 dengan persentase 60,22\% sehingga variabel Job Insecurity dalam perusahaan PT Mitra Sarana purnama berkategori Tinggi

Tabel 2. Rekapitulasi Skor Variabel Job Stress

\begin{tabular}{|c|c|c|c|}
\hline \multicolumn{1}{|c|}{ Indikator } & $\begin{array}{c}\text { Rata-rata } \\
\text { Skor }\end{array}$ & $\%$ & Keterangan \\
\hline Stress Lingungan & 199 & 51,53 & Cukup \\
\hline Stress Organisasi & 181,67 & 44,87 & Cukup \\
\hline Stress Individu & 169,33 & 40,12 & Cukup \\
\hline
\end{tabular}




\begin{tabular}{|l|l|l|l|}
\hline Rata-rata & 183,33 & 45,51 & Cukup \\
\hline
\end{tabular}

Berdasarkan Tabel 2 dapat dilihat bahwa nilai dari rata-rata jawaban responden mengenai variabel Job Stress berjumlah 183,33 dengan persentase $45,51 \%$ sehingga variabel Job Stress dalam perusahaan PT Mitra Sarana purnama berkategori Cukup

Tabel 3. Rekapitulasi Skor Variabel Kepuasan Kerja

\begin{tabular}{|c|c|c|c|}
\hline & $\begin{array}{c}\text { Rata-rata } \\
\text { Indikator }\end{array}$ & $\%$ & Keterangan \\
\hline $\begin{array}{c}\text { Skor } \\
\text { Pekerjaan itu sendiri }\end{array}$ & 267,33 & 77,82 & Tinggi \\
\hline $\begin{array}{c}\text { Kesempatan untuk } \\
\text { berkembang atau } \\
\text { promosi }\end{array}$ & 271 & 79,23 & Tinggi \\
\hline supervisi & 287,67 & 85,64 & Sangat tinggi \\
\hline Rata-rata & 275,33 & 80,90 & Sangat tinggi \\
\hline
\end{tabular}

Berdasarkan Tabel 3 dapat dilihat bahwa nilai dari rata-rata jawaban responden mengenai variabel Kepuasan Kerja berjumlah 275,33 dengan persentase 80,90\% sehingga variabel Kepuasan Kerja dalam perusahaan PT Mitra Sarana purnama berkategori Sangat Tinggi.

Tabel 4. koefisien Determinasi Job Insecurity terhadap kepuasan kerja karyawan

\begin{tabular}{|c|c|c|c|c|c|c|}
\hline \multicolumn{7}{|c|}{ Coefficient $^{\mathrm{a}}$} \\
\hline & & \multicolumn{2}{|c|}{$\begin{array}{l}\text { Unstandardized } \\
\text { Coefficients }\end{array}$} & $\begin{array}{c}\text { Standardized } \\
\text { Coefficients }\end{array}$ & $\mathrm{t}$ & Sig. \\
\hline \multicolumn{2}{|c|}{ Model } & B & Std. Error & Beta & & \\
\hline \multirow[t]{3}{*}{1} & (Constant) & 49.244 & 1.303 & & 37.800 & 0.000 \\
\hline & $\mathrm{x} 1$ & -0.303 & 0.044 & -0.528 & -6.812 & 0.000 \\
\hline & $\mathrm{x} 2$ & -0.315 & 0.053 & -0.460 & -5.941 & 0.000 \\
\hline
\end{tabular}

Dari hasil analisis pengaruh Job Inscurity terhadap kepuasan kerja karyawan didapat nilai thitung sebesar 6,812, sedangkan nilai ttabel dengan confidence level 95\% dan df $(n-k)=$ 62 , sebesar 1,998 .

Dengan demikian thitung sebesar 6,812> ttabel 1,998 dari hasil tersebut keputusan yang dapat diambil yaitu menolak Ho dan menerima Ha, maka job insecurity berpengaruh terhadap kepuasan kerja dalam issue Covid 19

Besar persentase variabel Job insecurity terhadap Kepuasan Kerja secara parsial

$\mathrm{Kd}=\beta \times$ Zero order $\times 100 \%$

$\mathrm{Kd}=-0,528 \times(-0,720) \times 100 \%=38,02 \%$

Artinya job insecurity memberikan kontribusi sebesar 38,02\% terhadap kepuasan kerja secara parsial.Artinya terdapat pengaruh rendah Job Insecurity terhadap kepuasan kerja karyawan

Tabel 5. koefisien Determinasi Job Stress terhadap kepuasan kerja karyawan

Coefficient $^{\mathrm{a}}$

\begin{tabular}{|l|c|c|c|c|c|}
\hline \multirow{3}{*}{ Model } & \multicolumn{2}{|c|}{$\begin{array}{c}\text { Unstandardized } \\
\text { Coefficients }\end{array}$} & $\begin{array}{c}\text { Standardized } \\
\text { Coefficients }\end{array}$ & $\mathrm{t}$ & Sig. \\
\cline { 2 - 6 } & $\mathrm{B}$ & Std. Error & Beta & & \\
\hline
\end{tabular}




\begin{tabular}{|ll|r|r|r|r|r|}
1 & (Constant) & 49.244 & 1.303 & & 37.800 & 0.000 \\
& $\mathrm{x} 1$ & -0.303 & 0.044 & -0.528 & -6.812 & 0.000 \\
& $\mathrm{x} 2$ & -0.315 & 0.053 & -0.460 & -5.941 & 0.000 \\
\hline
\end{tabular}

Dari hasil analisis Job Stress terhadap Kepuasan Kerja Karyawan didapat nilai thitung sebesar 5,941, sedangkan nilai ttabel dengan confidence level 95\% dan df $(n-k)=62$, sebesar 1,998.Dengan demikian thitung sebesar 5,941> ttabel 1,998 dari hasil tersebut keputusan yang dapat diambil yaitu menolak Ho dan menerima Ha, maka terdapat pengaruh variabel Job Stress (X2) terhadap kepuasan kerja (Y) dalam issue Covid 19 di PT Mitra Sarana Purnama Bandung

Besar persentase variabel Job stress terhadap kepuasan kerja secara parsial

$\mathrm{Kd}=\beta \times$ Zero order $\times 100 \%$

$\mathrm{Kd}=-0,460 \times(-0,681) \times 100 \%=31,32 \%$

Artinya job stress memberikan kontribusi sebesar $31,32 \%$ terhadap kepuasan kerja secara parsial. Artinya Job Stress memberi pengaruh rendah terhadap kepuasan kerja karyawan

Tabel 6. Hasil Uji regresi Linear berganda Job Insecurity dan Job Stress terhadap kepuasan kerja karyawan

Coefficient $^{\mathrm{a}}$

\begin{tabular}{|ll|r|r|r|r|r|}
\hline \multirow{2}{*}{ Model } & & \multicolumn{2}{|c|}{$\begin{array}{c}\text { Unstandardized } \\
\text { Coefficients }\end{array}$} & $\begin{array}{l}\text { Standardized } \\
\text { Coefficients }\end{array}$ & \multicolumn{1}{c|}{$\mathrm{t}$} & \multicolumn{1}{c|}{ Sig. } \\
\cline { 2 - 7 } & \multicolumn{1}{|c|}{ B } & \multicolumn{1}{c|}{ Std. Error } & Beta & & \\
\hline 1 & (Constant) & 49.244 & 1.303 & & 37.800 & 0.000 \\
& x1 & -0.303 & 0.044 & -0.528 & -6.812 & 0.000 \\
& x2 & -0.315 & 0.053 & -0.460 & -5.941 & 0.000 \\
\hline
\end{tabular}

Dari perhitungan Regresi Linear Berganda yang telah di olah maka didapatkan persamaan regresi linear seperti berikut $\mathrm{Y}=49,244-0,303 \mathrm{X} 1-0,315 \mathrm{X} 2$

Tabel 7. koefisien Determinasi Job Insecurity dan Job Stress terhadap kepuasan kerja karyawan

Model Summary ${ }^{\mathrm{b}}$

\begin{tabular}{|l|c|r|r|r|}
\hline Model & $\mathrm{R}$ & R Square & $\begin{array}{c}\text { Adjusted R } \\
\text { Square }\end{array}$ & $\begin{array}{c}\text { Std. Error of } \\
\text { the Estimate }\end{array}$ \\
\hline 1 & $.833^{\mathrm{a}}$ & 0.693 & 0.683 & 1.33256 \\
\hline
\end{tabular}

a. Predictors: (Constant), X2, X1

b. Dependent Variable: Y

Berdasarkan tabel diatas diperoleh nilai R Square sebesar 0,693. Artinya job insecurity dan job stress memberikan kontribusi sebesar 69,3\% terhadap kepuasan kerja, sedangkan sisanya sebesar $30,7 \%$ oleh faktor lain

\section{Kesimpulan}

1. Variabel Job Insecurity dalam issue covid-19 yang berada di perusahaan PT Mitra Sarana Purnama Bandung berada di dalam kategori cukup.

2. Variabel Job Stress dalam issue Covid-19 yang berada di perusahaan PT Mitra Sarana Purnama Bandung berada di dalam kategori tinggi

3. Variabel Kepuasan kerja karyawan dalam issue Covid-19 yang berada di perusahaan PT Mitra Sarana Purnama Bandung berada di dalam kategori sangat tinggi

4. Terdapat pengaruh rendah yaitu sebesar $38,02 \%$ antara Job Insecurity terhadap kepuasan kerja karyawan dalam issue Covid-19 di PT Mitra Sarana Purnama Bandung

5. Terdapat pengaruh rendah 31,32\% signifikan antara Job Stress terhadap kepuasan kerja 
karywan dalam Issue Covid-19 di PT Mitra Sarana Purnama Bandung

6. Berdasarkan uji hipotesis secara simultan, variabel Job Insecurity (X1) dan Job Stress (X2) memiliki pengaruh terhadap variabel kepuasan kerja (Y) dalam issue Covid-19, dengan nilai $\mathrm{R}$ square sebesar 0,693 . Artinya Job insecurity dan Job stress memberikan pengaruh kuat sebesar $69,3 \%$ terhadap kepuasan kerja karyawan, sedangkan sisanya sebesar $30,7 \%$ oleh faktor lain

\section{Daftar Pustaka}

[1] A.A Gede Agung Januartha, D. (2019). PENGARUH JOB INSECURITY DAN KEPUASAN KERJA TERHADAP TURNOVER INTENTION PADA KARYAWAN HOTEL. E-Jurnal Manajemen, Vol. 8, No. 2.

[2] connor. (2018). pengaruh kepuasan kerja terhadap kinerja karyawan PT Indah permata. E journal Management.

[3] Dewi, I. G. (2019). PENGARUH STRES KERJA TERHADAP KEPUASAN KERJA DENGAN. E-Jurnal Manajemen Unud, Vol. 8, No. 3.

[4] I Gede Putro Wibowo, G. R. (2015). PENGARUH STRES KERJA TERHADAP KEPUASAN KERJA. E-Jurnal Ekonomi dan Bisnis Universitas Udayana 4.02, 137.

[5] I Gede Riana, M. M. (2017). IMPLIKASI JOB INSECURITY TERHADAP KEPUASAN KERJA DAN INTENTION TO LEAVE . Jurnal Ekonomi dan Keuangan .

[6] KEMENKES. (2021, Maret Rabu). Line Siaga Bersama \#Siaga Covid 19. Retrieved from Line Siaga Bersama \#Siaga Covid 19: https://siaga.line.me/covid19

[7] Mangkunegara. (2015). Manajemen Sumber Daya Manusia Perusahaan. Bandung: PT. Remaja Rosdakarya.

[8] Manurung, F. (2019). PENGARUH JOB INSECURITY, KOMPENSASI DAN LINGKUNGAN KERJA TERHADAP KEPUASAN KERJA KARYAWAN PADA PT EXPRAVET NASUBA MEDAN. skripsi PROGRAM STUDI STRATA 1 MANAJEMEN EKSTENSI DEPARTEMEN MANAJEMEN FAKULTAS EKONOMI DAN BISNIS UNIVERSITAS SUMATERA UTARA MEDAN, 94 - 95.

[9] Masum. A. K. M, M. A. (2016). Job satisfaction and inten- tion to quit: an empirical analysis of nurses in Turkey. peer journal, 1-23.

[10] pemerintah, P. (2020). Peraturan Pemerintah (PP) tentang Pembatasan Sosial Berskala Besar dalam Rangka Percepatan Penanganan Corona Virus Disease 2019 (COVID-19). LN.2020/NO.91, TLN NO.6487, JDIH.SETNEG.GO.ID : 5 HLM.

[11] Perdana, N. k. (2016). "Pengaruh Job Insecurity dan Stres Kerja Terhadap Turnover Intention karyawan pada hotel Asana Agung Putra Bali”, . -Jurnal Manajemen Unud, , 6432.

[12] Riana, I. G. (2015). Effects Motivation On Business Performance: The Mediation Role of Job Satisfaction And Leadership (A Study In Village Credit Institutions). . European Journal of Business, Economics and Accountancy, 1-11.

[13] Robbins, P. S. (2017). Organizational Behaviour, Edisi 13, jilid 1. jakarta: salemba empat.

[14] Sutrisno, E. (2018). Manajemen Sumber Daya Manusia. jakarta: Prenadamedia.

[15] Sverke, d. (2015). "No Security: A Meta-Analysis and Review of Job Insecurity and its Consequences". Journal of Occupational Helth Psychology 7, 244-255.

[16] Tania Dehesh, H. M.-F. (2020). Forecasting of COVID-19 Confirmed Cases in Different Countries with ARIMA Models. 
https://doi.org/10.1101/2020.03.13.20035345.

[17] WHO. (2021). Retrieved from WHO Coronavirus disease (COVID19) Dashboard: https://covid19.who.int?gclid=EAIaIQobChMlufDWIPnY6QIVIQ4rCH1_EgWg EAAYASABEgLv5vD_BwE

[18] Y Akgunduz, G. E. (2018). Does turnover intention mediate the effects of job insecurity and co-worker support on social loafing? International Journal of Hospitality Management, 41- 49. 